ISSN: 2338-8021; E-ISSN: 2338-8269

\title{
HUBUNGAN TINGKAT PENGETAHUAN LOKAL MASYARAKAT DESA CIHERANG DENGAN TINGKAT PENGELOLAAN TANAMAN OBAT KELUARGA
}

\author{
The Relationship Between Community Knowledge and Management of TOGA
}

\author{
Ike Rosmanita $^{1)}$ dan Saharuddin ${ }^{1)}$ \\ ${ }^{1)}$ Departemen Sains Komunikasi dan Pengembangan Masyarakat, Fakultas Ekologi Manusia, \\ Institut Pertanian Bogor, Darmaga Bogor 16680, Indonesia \\ Email: ikerosmanita@gmail.com; saharuddin@apps.ipb.ac.id
}

\begin{abstract}
Local knowledge is a basic resource who passed down from one generation to another generation. Every region has a different knowledge to manage and utilize plants in the yard including medicinal plants. This study try to analyze the condition of the yard agroekosistem, analyze the level of local knowledge about medicinal plants, analyze level management of medicinal plants, analyze the relationship between level of local knowledge with the level management of mrdicinal plants, and analyze the relationship between local knowledge with condition of yard agroekosistem. This reseach used a quantitative approach and supported with qualitative approach as a method of reseach. The results showed condition of yard agroekosistem has a good condition and people have used their yard around the house. The results also showed that the level of local knowledge about medicinal plants classified as moderate. Beside that the level managemet of medicinal plants classified in the high category. Based on statistical tests, we can know that there is no relationship between local knowledge with the level management of medicinal plants.
\end{abstract}

Keywords: health, livelihood, medicinal plants, yard

\begin{abstract}
ABSTRAK
Pengetahuan lokal merupakan pengetahuan yang diwariskan secara turun temurun dari satu generasi kapada generasi berikutnya. Masing-masing wilayah memiliki pengetahuan tersendiri dalam pengelolaan dan pemanfaatan berbagai tanaman termasuk tanaman obat. Tujuan penelitian ini adalah untuk menganalisis kondisi agroekosistem pekarangan masyarakat, menganalisis tingkat pengetahuan lokal masyarakat mengenai tanaman obat, menganalisis tingkat pengelolaan tanaman obat, menganalisis hubungan pengetahuan lokal dengan tingkat pengelolaan tanaman obat, dan menganalisis hubungan pengetahuan lokal dengan kondisi agroekosistem pekarangan. Metode yang digunakan adalah pendekatan kuantitatif dan didukung dengan pendekatan kualitatif. Hasil penelitian menunjukkan bahwa agroekosistem pekarangan masyarakat sudah dimanfaatkan secara optimal. Hal ini dapat dilihat dari kondisi pekarangan masyarakat yang ditanam berbagai jenis tanaman termasuk tanaman obat. Hasil penelitian juga menunjukkan bahwa tingkat pengetahuan lokal masyarakat mengenai tanaman obat tergolong sedang, sedangkan tingkat pengelolaan tanaman obat tergolong dalam kategori tinggi. Berdasarkan uji statistik yang dilakukan, tidak terdapat hubungan antara pengetahuan lokal dengan tingkat pengelolaan tanaman obat.
\end{abstract}

Kata kunci: kesehatan, nafkah, pekarangan, tanaman obat

\section{PENDAHULUAN}

Pekarangan merupakan salah satu aspek yang erat kaitannya dengan kehidupan manusia. Letak pekarangan yang dekat dengan tempat tinggal menyebabkan pekarangan sering dimanfaatkan sebagai area untuk menunjang berbagai aktivitas, mulai dari area bermain dan berkumpul keluarga hingga sebagai area untuk bercocok tanam berbagai jenis tanaman yang bermanfaat bagi manusia. Hal ini menunjukkan bahwa pekarangan dapat memberikan manfaat yang besar khususnya bagi rumah tangga yang mengelola dan memanfaatkan lahan pekarangan di sekitar tempat tinggal mereka. Kegiatan budidaya dan bercocok tanam di pekarangan dapat dilakukan dengan menanam berbagai jenis tanaman mulai dari tanaman hias, tanaman buah, hingga tanaman obat. Pengelolaan dan pemanfaatan pekarangan sebagai salah-satu bagian dari lingkungan memerlukan peran serta dan partisipasi aktif dari semua pihak, termasuk masyarakat lokal yang berada di sekitar lingkungan yang dimanfaatkan. Masyarakat lokal yang telah mengenal lingkungan mereka dengan baik memiliki aturan yang tercermin dalam pengetahuan lokal guna menjamin 
pengelolaan sumber daya alam yang selaras alam. Pengetahuan lokal yang ada lahir, tumbuh, dan diwariskan oleh masyarakat lokal secara turun temurun dari satu generasi ke generasi berikutnya. Pengetahuan lokal umumnya diwariskan secara lisan sehingga jarang ditemukan dokumentasi tertulis mengenai pengetahuan lokal yang dimiliki oleh masyarakat.

Sunaryo dan Joshi (2003) mengemukakan bahwa pengetahuan lokal merupakan konsep yang merujuk pada pengetahuan yang dimiliki oleh sekelompok orang yang hidup di wilayah tertentu untuk jangka waktu yang lama. Hasil penelitian yang dilakukan oleh Suryana, Iskandar, dan Supratman (2014) menunjukkan bahwa pengetahuan lokal berperan penting bagi masyarakat di Desa Cibunar dalam memanfaatkan tanaman sebagai media pengobatan. Pengetahuan masyarakat di Desa Cibunar tentang tanaman obat dimanfaatkan sebagai pengobatan tradisional. Pengetahuan mengenai pengobatan dengan menggunakan tanaman obat umumnya didapat dari hasil interaksi dan komunikasi dalam kehidupan mereka sehari-hari dengan masyarakat sekitarnya. Hal tersebut terutama didapat melalui lisan, seperti diperoleh dengan cara mendengar dari orang tuanya $(50.49 \%)$ dan ada pula yang diperoleh secara terbatas dari hasil membaca dari bahan-bahan bacaan. Hal ini menunjukkan pengetahuan lokal berperan penting dalam berbagai aspek kegiatan manusia.

Pengetahuan lokal yang tumbuh dan berkembang dalam masyarakat perlu dilestarikan guna menjamin keberlangsungan pengetahuan lokal yang ada. Namun seiring dengan perkembangan zaman dan masuknya modernisasi seperti perkembangan sarana transportasi, masuknya listrik, televisi, hingga media dan sarana komunikasi telah mengakibatkan perubahan gaya hidup masyarakat. Masyarakat cenderung menginginkan gaya hidup yang praktis dan instan sehingga sudah mulai jarang memanfaatkan lahan pekarangan yang ada di sekitar tempat tinggal. Selain itu penyebaran informasi yang berkaitan dengan pengetahuan lokal mengenai tanaman obat sudah mulai jarang dilakukan dari generasi satu ke generaasi berikutnya. Hal ini didukung oleh hasil penelitian yang dilakukan oleh Suryana, Iskandar, dan Supratman (2014) yang menunjukkan bahwa masyarakat di Desa Cibunar masih menerapkan pengetahuan lokal tentang tanaman obat yang dimiliki. Namun bila dilihat perkembangannya dalam sepuluh tahun terakhir pengetahuan lokal masyarakat Desa Cibunar tentang tanaman obat cenderung menurun sejalan dengan meningkatnya penggunaan obat-obatan modern dan meningkatnya pelayanan fasilitas pengobatan modern. Makin rendahnya kesadaran masyarakat dalam memanfaatkan pekarangan ini menyebabkan pekarangan tidak dimanfaatkan secara optimal. Padahal tanaman yang terdapat di lingkungan pekarangan dapat dimanfaatkan dengan baik dan dapat memberikan berbagai manfaat, mulai dari manfaat kesehatan, estetika atau keindahan, hingga memberikan manfaat ekonomi dan menjadi sumber nafkah. Hal ini sejalan dengan pendapat yang dikemukakan oleh Suharti (2014) yang menyatakan bahwa lahan pekarangan yang ada dapat dimanfaatkan sebagai lumbung hidup, apotek hidup atau sekaligus sebagai penambah kehidupan. Tanaman yang ada di pekarangan jika mampu dikelola dan dimanfaatkan dengan baik dapat dijadikan sebagai sumber nafkah tambahan bagi masyarakat.

Pemanfaatan dan pengelolaan pekarangan sebagai salah satu lingkungan yang menunjang kehidupan manusia dapat dilihat pada pekarangan masyarakat yang ada di Desa Ciherang. Masyarakat yang berdomisili di desa ini umumnya memiliki pekarangan di sekitar tempat tinggal mereka meskipun lahan yang dimiliki tidak terlalu luas. Pekarangan yang ada dimanfaatkan untuk berbagai keperluan termasuk menanam berbagai jenis tanaman mulai dari tanaman hias hingga tanaman obat. Desa ini masih didominasi oleh penduduk asli atau penduduk lokal sehingga pengetahuan yang ada dan berkembang dalam masyarakat khususnya mengenai pengelolaan dan pemanfaatan lingkungan masih didasarkan pada pengetahuan lokal yang dimiliki. Namun seperti yang telah dikemukakan sebelumnya, perkembangan teknologi yang ada ikut berpengaruh terhadap perkembangan obatobatan medis bagi kesehatan masyarakat. Masyarakat mulai mengenal serta menggunakan obat-obatan medis sehingga tingkat konsumsi obat-obatan tradisional yang didasarkan pada pengetahuan lokal mulai berkurang. Hal ini 
menunjukkan bahwa pengetahuan lokal mengenai tanaman obat yang terdapat di pekarangan menjadi salah-satu komponen penting yang perlu diperhatikan dan ditingkatkan kembali di masyarakat.

Berdasarkan pemaparan yang telah dikemukakan, masalah penelitian yang dirumuskan dalam penelitian ini adalah: 1) Bagaimana kondisi agroekosistem pekarangan masyarakat? 2) Bagaimana tingkat pengetahuan lokal masyarakat mengenai tanaman obat? 3) Bagaimana tingkat pengelolaan tanaman obat masyarakat? 4) Bagaimana hubungan tingkat pengetahuan lokal dengan tingkat pengelolaan tanaman obat? 5) Bagaimana hubungan pengetahuan lokal dengan agroekosistem pekarangan masyarakat? Mengacu pada masalah penelitian yang telah dirumuskan, tujuan penelitian ini adalah menganalisis kondisi agroekosistem pekarangan masyarakat, menganalisis tingkat pengetahuan lokal masyarakat mengenai tanaman obat, menganalisis tingkat pengelolaan tanaman obat, menganalisis hubungan tingkat pengetahuan lokal dengan tingkat pengelolaan tanaman obat, dan menganalisis hubungan pengetahuan lokal dengan agroekosistem pekarangan masyarakat.

\section{PENDEKATAN TEORITIS}

Marten (1988) mengemukakan bahwa agroekosistem merupakan kesatuan udara, air, tanah, tanaman, hewan, mikro organisme, dan sebagainya yang terdapat di wilayah tertentu dan bersifat terbatas dimana aktor-aktor yang terlibat melakukan modifikasi untuk keperluan produksi pertanian. Salah satu bentuk agroekosistem yang dekat dengan manusia adalah agroekosistem pekarangan. Keberhasilan pemanfaatan pengelolaan pekarangan berbasis agroekosistem dapat dilihat dari beberapa indikator. Marten (1988) mengemukakan lima indikator keberhasilan yang terdiri dari produktivitas, stabilitas, keberlanjutan, pemerataan dan otonomi atau kebijakan. Kelima indikator tersebut memiliki keterkaitan satu sama lain. Namun penelitian ini hanya menggunakan tiga indikator yaitu kebijakan, keberlanjutan, dan pemerataan. Kebijakan yang merujuk pada Marten (1988) yaitu kebijakan berkaitan dengan gelar agroekosistem tentang integrasi, seperti pergerakan bahan, energi, dan informasi antar bagian komponennya, informasi masuk dan keluar dari agroekosistem serta kontrol gerakan tersebut. Keberlanjutan melibatkan kemampuan manajemen untuk mempertahankan agroekosistem pekarangan, sedangkan pemerataan merupakan distribusi produk pertanian atau pendapatan. Pemerataan dapat dinilai sebagai suatu distribusi produk pertanian atau distribusi akses ke input pertanian seperti tanah, modal atau informasi teknis. Hal ini menunjukkan bahwa dalam pengelolaan tanaman pertanian berbasis agroekosistem pekarangan diperlukan pengelolaan yang mandiri dimana aktor-aktor lokal memiliki peranan dalam menentukan kebijakan atau tata kelola agroekosistem pekarangan.

Pengelolaan agroekosistem pekarangan tidak dapat dipisahkan dari pengetahuan lokal yang dimiliki oleh masyarakat. Menurut Sunaryo dan Joshi (2003) pengetahuan lokal merupakan konsep yang lebih luas yang merujuk pada pengetahuan yang dimiliki oleh sekelompok orang yang hidup di wilayah tertentu untuk jangka waktu yang lama. Lebih lanjut Sunaryo dan Joshi (2003) mengemukakan bahwa pengetahuan lokal suatu masyarakat petani yang hidup di lingkungan wilayah yang spesifik biasanya diperoleh berdasarkan pengalaman yang diwariskan secara turun-temurun. Pendapat yang dikemukakan oleh Sunaryo dan Joshi juga didukung oleh tokoh lain, diantaranya adalah Mitchell et. al. Mitchell et al. Seperti yang dikutip Hudin (2010) mengemukakan bahwa pengetahuan lokal merupakan kumpulan pengetahuan dan cara berpikir yang berakar dalam kebudayaan suatu kelompok masyarakat yang merupakan hasil pengamatan selama kurun waktu yang lama.

Pengelolaan pekarangan berbasis pengetahuan lokal yang dimiliki oleh masyarakat dapat memberikan keuntungan dan manfaat yang besar bagi rumah tangga bila mampu dimanfaatkan dengan baik. Pekarangan dapat memberikan berbagai manfaat mulai dari manfaat estetika hingga manfaat ekonomi dan dijadikan sebagai strategi nafkah masyarakat. Ellis (2000) juga mengemukakan bahwa strategi nafkah adalah strategi sumber mata pencaharian yang terdiri dari kegiatan yang menghasilkan sarana kelangsungan hidup rumah tangga. Pendpt yang dikemukakan oleh Ellis ini kemudian digunakan untuk mengukur tingkat pengelolan tanaman obat sebagai alternatif nafkah masyarakat. 
Kerangka pemikiran yang dirumuskan berdasarkan studi literatur yang ada dapat dilihat pada Gambar 1.

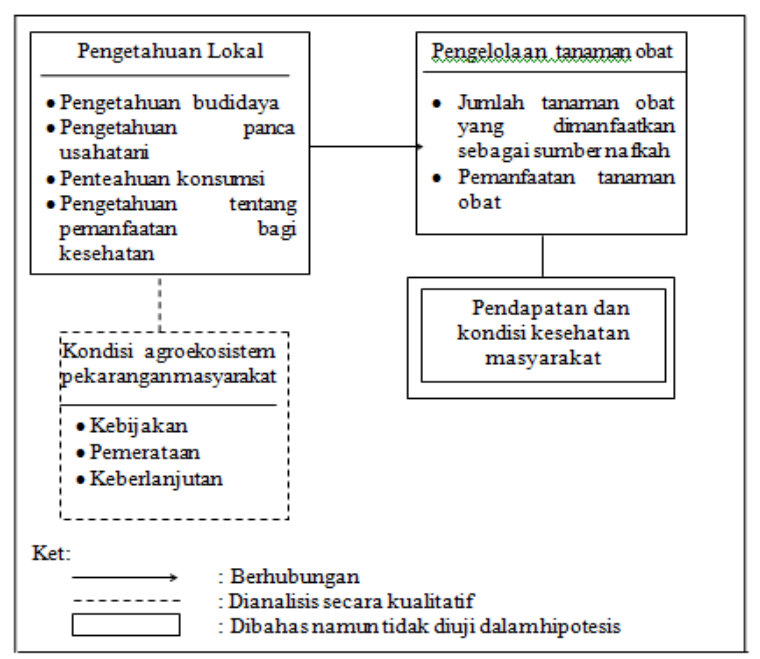

Gambar 1 Kerangka pemikiran hubungan pengetahuan lokal masyarakat dengan tingkat pengelolaan tanaman obat keluarga

\section{PENDEKATAN LAPANG}

Metode yang digunakan dalam penelitian ini adalah metode penelitian survei. Singarimbun dan Effendi (2006) mengemukakan bahwa penelitian survei merupakan penelitian yang mengambil sampel dari satu populasi dan menggunakan kuesioner sebagai alat pengumpulan data yang pokok. Penelitian yang dilakukan juga didukung dengan metode observasi atau pengamatan langsung dan wawancara mendalam terhadap informan yang didasarkan pada panduan wawancara yang telah disiapkan sebelumnya.

Penelitian dilaksanakan di Desa Ciherang, Bogor, Jawa Barat. Penentuan lokasi penelitian ini ditetapkan secara sengaja dengan pertimbangan masyarakat Desa Ciherang masih memanfaatkan lahan pekarangan dengan menanam berbagai jenis tanaman termasuk tanaman obat meskipun lahan yang dimiliki tidak terlalu luas. Hal ini sesuai dengan fokus penelitian yang dikaji dalam penelitian. Penelitian dilakukan pada Bulan Februari-Maret 2015 yang mencakup waktu selama peneliti melakukan proses pengumpulan data di lapangan.

Jenis data yang dikumpulkan dalam penelitian ini adalah data primer dan data sekunder. Data primer merupakan data yang diperoleh dari wawancara dengan responden dan informan serta menggunakan metode survey yang dilengkapi dengan kuesioner, sedangkan data sekunder meliputi data potensi desa yang diperoleh dari kantor desa, serta literatur lain yang terkait. Pendekatan yang digunakan dalam penelitian ini adalah pendekatan kuantitatif yang didukung oleh pendekatan kualitatif. Langkah berikutnya adalah penentuan responden penelitian. Responden penelitian ditetapkan berdasarkan populasi yang ada di lokasi penelitian. Populasi dalam penelitian ini yang sekaligus menjadi populasi sasaran penelitian adalah keseluruhan rumah tanga yang menanam tanaman obat di lahan pekarangan. Berdasarkan populasi yang ada kemudian ditentukan unit analisis untuk mempermudah proses pengumpulan data. Unit analisis yang digunakan dalam penelitian ini adalah rumah tangga yang menanam tanaman obat di lahan pekarangan yang berjumlah sebanyak 85 rumah tangga yang tersebar di RW 08 dan RW 11. Penelitian ini menggunakan teknik sensus, dimana keseluruhan rumah tangga yang menanam tanaman obat di lahan pekarangan ditetapkan sebagai responden penelitian. Teknik ini dipilih untuk mewakili keseluruhan karakteristik rumah tangga yang ada di Desa Ciherang.

Hasil pengumpulan data yang diperoleh di lapangan melalui kuesioner diolah dan dianalisis dengan software Microsoft Excel 2007 dan tabulasi silang dengan menggunakan SPSS for Windows 16.0 Laporan hasil penelitian juga dilengkapi dengan data deskriptif. Penyajian data secara deskriptif dilakukan untuk pengolahan dan analisis data kualitatif yang diperoleh dari observasi dan wawancara mendalam. Hal ini dilakukan untuk memperkuat dan memberikan penjelasan lebih lanjut data kuantitatif yang diperoleh. Pengolahan data kualitatif ini terdiri dari tiga tahap, yaitu reduksi data, penyajian data, dan penarikan kesimpulan.

\section{HASIL DAN PEMBAHASAN}

\section{Analisis Kondisi Agroekosistem Pekarangan Masyarakat Desa Ciherang}

\section{Identifikasi dan Gambaran Umum Tanaman Obat di Pekarangan}

Pekarangan merupakan salah satu aspek penting yang tidak dapat dipisahkan dari kehidupan 
manusia. Pekarangan dapat dimanfaatkan dengan menanam berbagai jenis tanaman mulai dari tanaman hias, tanaman buah, hingga tanaman obat. Fakta di lapang menunjukkan bahwa terdapat beberapa tanaman obat yang umum ditanam di pekarangan masyarakat. Terdapat $68.2 \%$ masyarakat yang menanam cabe rawit di lahan pekarangan. Tanaman dominan berikutnya yang ditanam oleh masyarakat adalah jambu batu dimana terdapat $58.8 \%$ masyarakat menanam tanaman tersebut di pekarangan. Tanaman pandan wangi juga banyak ditanam oleh masyarakat di pekarangan. Hal ini dapat dilihat dari persentase masyarakat yang menanam tanaman pandan wangi di pekarangan sebesar $55.3 \%$. Tanaman lain yang sering dijumpai di lahan pekarangan masyarakat yaitu kunyit, jahe, kencur, katuk, kumis kucing, salam dan lidah buaya. Tanaman ini banyak ditanam oleh masyarakat karena selain bermanfaat bagi kesehatan, tanaman yang ada juga dapat memberikan manfaat lain mulai dari manfaat estetika hingga manfaat ekonomi. Manfaat estetika dapat dirasakan dari pekarangan yang lebih sejuk dan dapat berperan sebagai alternatif penghijauan bagi lingkungan sekitar, sedangkan manfaat ekonomi dapat dirasakan dengan memanfaatkan tanaman tersebut bagi keperluan dapur hingga dapat dijadikan sebagai sumber nafkah atau penghasilan bagi rumah tangga.

Tanaman obat yang dominan ada di pekarangan masyarakat ini umumnya memiliki beragam khasiat dan kegunaan. Bagian tanaman obat yang ada dapat dimanfaatkan untuk memenuhi kebutuhan rumah tangga. Tanaman cabe rawit misalnya, selain dapat dimanfaatkan buahnya untuk memenuhi kebutuhan rumah tangga, daun cabe rawit juga dapat dimanfaatkan sebagai obat sakit perut. Tanaman cabe rawit merupakan tanaman yang familiar dan dikenal oleh masyarakat Desa Ciherang. Selain tanaman cabe rawit, tanaman jambu batu juga banyak ditanam di lahan pekarangan meskipun ukuran tanaman ini relatif besar. Hal ini dikarenakan jambu batu memiliki banyak khasiat. Masyarakat Desa Ciherang mengemukakan bahwa jambu batu selain buahnya dapat di konsumsi langsung, daun jambu batu juga bermanfaat bagi kesehatan masyarakat. Tanaman lain yang kerap dijumpai di pekarangan masyarakat Desa Ciherang yaitu tanaman rempah-rempah atau yang sering dijadikan sebagai bumbu dapur, sayur dan juga pewangi pada makanan seperti tanaman pandan wangi, kunyit, jahe, kencur, katuk, dan salam.

Tanaman yang biasa di tanam di pinggiran pekarangan atau sering juga dijadikan sebagai pagar oleh warga Desa Ciherang yaitu tanaman kumis kucing, tanaman dengan bunga warna putih ini biasanya digunakan oleh masyarakat bagi kesehatan. Berbeda halnya dengan tanaman kumis kucing, tanaman lidah buaya umumnya ditanam oleh masyarakat menggunakan media pot atau polibag. Tanaman yang tidak memiliki dahan atau pun daun ini cocok ditanam menggunakan media tanam dan tidak terlalu banyak menggunakan lahan, namun mampu tumbuh dan berkembang dengan baik. Tanaman ini umumnya dimanfaatkan untuk meningkatkan kesuburan pada rambut yang relatif tipis.

\section{Kebijakan Masyarakat dalam Mengelola Tanaman Obat}

Rumah tangga yang ada di Desa Ciherang memiliki aturan dan kebijakan sendiri dalam pengelolaan dan pemanfaatan tanaman obat. Setiap rumah tangga memiliki kebijakan dalam hal mengelola lahan pekarangan. Keputusan yang ada sepenuhnya menjadi hak dari rumah tangga yang memiliki lahan pekarangan itu sendiri. Selain memiliki kontrol penuh terhadap tanaman obat yang akan ditanam di lahan pekarangan yang mereka miliki, rumah tangga juga memiliki kontrol dan kebijakan sendiri dalam mengatur masa panen, pemanfaatan hasil panen tanaman, hingga penyebarluasan hasil produksi, bibit, dan informasi kepada pihak lain.

Informasi mengenai khasiat dan manfaat tanaman obat yang ada di lahan pekarangan sering disampaikan oleh kerabat atau tetangga sekitar. Namun informasi yang disampaikan ini tidak secara langsung diterima oleh rumah tangga. Keputusan untuk membudidayakan tanaman obat tetap berada pada kebijakan dan kesediaan rumah tangga yang memiliki pekarangan. Kebijakan dalam pengelolaan tanaman obat pada tingkatan yang lebih luas dapat dilihat pada kebijakan masyarakat Desa Ciherang secara keseluruhan. Secara umum masyarakat Desa Ciherang memiliki tokoh atau masyarakat yang "dituakan" dalam penyebaran informasi. Masyarakat akan bertanya mengenai khasiat dan manfaat dari tanaman obat kepada warga yang "dituakan" tersebut. 


\section{Keberlanjutan Tanaman Obat di Lahan Pekarangan}

Populasi tanaman obat yang ditanam di lahan pekarangan masyarakat cenderung tidak terlalu besar. Masyarakat Desa Ciherang yang membudidayakan tanaman obat hanya menanam satu atau beberapa jenis tanaman. Hal ini disebabkan kebutuhan akan tanaman tersebut yang tidak terlalu mendesak dan dapat digunakan dalam jumlah yang tidak terlalu banyak. Selain itu, ada pula masyarakat yang menanam tanaman obat di pekarangan dengan niat mencoba-coba atau iseng saja, sehingga jumlah tanaman yang ditanam di pekarangan tidak terlalu banyak. Namun lambat laun tanaman yang ada di pekarangan ini berkembang biak. Melihat potensi dan jumlah tanaman yang semakin banyak, warga yang menanam mulai memindahkan dan menanam kembali tanaman tersebut di tempat yang berbeda. Meskipun demikian ada pula warga yang menanam tanaman obat di pekarangan karena didasarkan pada pengetahuan akan manfaat dan kebutuhan akan tanaman obat tersebut. Kondisi ini menjamin keberjanjutan tanaman yang ditanam.

Keberlanjutan tanaman obat yang ada di pekarangan masyarakat Desa Ciherang juga dilihat dari upaya yang dilakukan masyarakat dalam merawat, mengelola, dan memanfaatkan tanaman obat. Masyarakat mampu merawat dan mengatur pemanenan atau pemanfaatan tanaman obat agar digunakan seperlunya Pengelolaan dalam proses pemanenan dapat dilakukan dengan cara yang tepat dan sesuai dengan kebutuhan. Contoh sederhana yang dilakukan oleh masyarakat dalam memanen tanaman obat seperti memetik daun tanaman tanpa harus mematahkan batang tanaman, mengambil umbi tanpa harus mencabut seluruh bagian tanaman hingga memetik buah atau bunga tanaman yang sudah siap dipanen dan sesuai dengan kebutuhan atau tidak mengambil secara berlebihan.

\section{Pemerataan dan Penyebaran Tanaman Obat}

Hasil produksi tanaman obat yang ada di pekrangan selain dikonsumsi dan dimanfaatkan sendiri oleh rumah tngga, hasil produksi juga didistribusikan kepada kerabat atau tetangga sekitar yang membutuhkan baik melalui pemberian secara sukarela maupun dijual. Hal ini menunjukkan bahwa masyarakat yang ada di Desa Ciherang memiliki rasa kepedulian dan rasa saling berbagi yang tinggi satu sama lain dalam menyebarkan hasil produksi tanaman obat yang dimiliki kepada warga lain. Pemerataan yang dilakukan oleh masyarakat Desa Ciherang dapat pula dilihat dari penyebaran bibit tanaman obat yang dimiliki oleh masyarakat. Masyarakat yang memiliki tanaman obat dan sudah berkembang biak serta memiliki anakan tidak merasa keberatan jika ada salah satu warga yang meminta bibit tersebut. Bentuk pemerataan dan penyebaran lainnya yang dilakukan oleh masyarakat Desa Ciherang adalah dengan menyebarkan informasi mengenai khasiat dan manfaat tanaman obat kepada pihak lain. Berdasarkan hal yang telah dikemukakan, maka tampak bahwa masyarakat Desa Ciherang telah mampu melakukan proses pemerataan dan penyebaran hasil produksi tanaman obat.

\section{Pengetahuan Mengenai Tanaman Obat}

\section{Pengetahuan Mengenai Budidaya Tanaman Obat}

Pekarangan masyarakat Desa Ciherang ditanami dengan berbagai jenis tanaman yang dirasa bermanfaat bagi masyarakat. Kegiatan menanam didasarkan pada pengetahuan masyarakat mengenai tanaman obat khususnya dalam hal budidaya. Pengetahuan lokal mengenai budidaya tanaman obat dapat diukur menggunakan tiga indikator pengukuran yang terdiri dari pengetahuan, sikap dan tindakan. Berdasarkan hasil pengumpulan data yang telah dilakukan di lapang diperoleh bahwa secara umum tingkat pengetahuan lokal masyarakat Desa Ciherang mengenai budidaya tanaman obat tergolong sedang dengan persentase sebesar $52.9 \%$. Hal ini disebabkan karena tidak semua tanaman obat dapat dijumpai di lahan pekarangan masyarakat. Penyebaran informasi mengenai khasiat dan manfaat tanaman obat yang ada di lahan pekarangan juga cenderung tidak merata. Masyarakat umumnya akan berbagi informasi hanya ketika ada yang sakit atau bertanya secara langsung kepada orang yang dianggap lebih tahu mengenai tanaman obat. Meskipun demikian, masyarakat yang tergolong dalam kategori rendah memiliki persentase $0.0 \%$ atau tidak ada masyarakat yang tergolong dalam kategori tidak mengenal tanaman obat di lahan pekarangan mereka. 
Indikator kedua yang digunakan untuk mengukur tingkat pengetahuan lokal mengenai budidaya tanaman obat yaitu sikap. Data yang diperoleh menunjukkan bahwa masyarakat setuju untuk membudidayakan tanaman obat di lahan pekarangan mereka dengan persentase sebesar $80.0 \%$. Masyarakat Desa Ciherang setuju untuk membudidayakan tanaman obat di lahan pekarangan karena mereka beranggapan bahwa setiap tanaman obat pasti memiliki khasiat serta kegunaan, walaupun masih ada dari masyarakat yang belum mengetahui semua jenis dan kegunaan dari tanaman obat yang ada. Persepsi masyarakat tentang setiap tanaman obat pasti memiliki khasiat dan kegunaan tidak lepas dari keyakinan atau kepercayaan dari masyarakat tentang khasiat yang diberikan dari tanaman obat itu sendiri.

Indikator terakhir yang digunakan adalah tindakan. Data yang diperoleh menunjukkan bahwa $87.1 \%$ tindakan masyarakat tergolong dalam kategori rendah. Hal ini dikarenakan lahan pekarangan yang tersedia relatif sempit. Selain itu, terdapat beberapa jenis tanaman obat yang tumbuh liar di pinggiran jalan, di kebun, hingga di sawah. Kondisi ini membuat sebagian besar masyarakat merasa kurang perlu untuk membudidayakan tanaman tersebut di lahan pekarangan.

Berdasarkan data yang diperoleh dari ketiga indikator yang telah dipaparkan pada bagian sebelumnya, maka dapat dirumuskan tingkat pengetahuan lokal mengenai budidaya tanaman obat. Tingkat pengetahuan lokal masyarakat Desa Ciherang mengenai budidaya tanaman obat tergolong sedang dengan persentase sebesar $55.3 \%$. Hal ini dikarenakan pada indikator pengetahuan masyarakat mengenai budidaya tanaman obat tergolong sedang. Masyarakat Desa Ciherang secara umum telah mengenal tanaman obat yang ada di lahan pekarangan. Namun adapula beberapa tanaman obat yang kurang familiar karena tanaman tersebut jarang dimanfaatkan oleh masyarakat. Bila dianalisis berdasarkan aspek sikap, mayoritas masyarakat menyatakan setuju untuk membudidayakan tanaman obat tersebut. Namun, hasil ini tidak sejalan dengan tindakan yang dilakukan oleh masyarakat Desa Ciherang dimana tindakan masyarakat dalam menanam tanaman obat di lahan pekarangan cenderung rendah atau banyak dari masyarakat yang tidak menanam. Hal ini disebabkan karena adanya pertimbangan luas lahan pekarangan yang kurang memadai.

\section{Pengetahuan Tentang Panca Usahatani Tanaman Obat}

Panca usahatani mengenai budidaya tanaman obat terdiri dari 5 aspek yaitu bibit, penggunaan pupuk, pemeliharaan, pengolahan lahan dan pengairan. Pengetahuan masyarakat mengenai panca usahatani tanaman obat tersebar pada kategori sedang dengan persentase sebesar $68.2 \%$. Pengetahuan masyarakat yang berada pada kategori sedang ini disebabkan karena pengetahuan masyarakat dalam membudidayakan tanaman obat di lahan pekarangan hanya bersumber pada pengalaman dan kebiasaan yang telah umum dilakukan. Bila dilihat berdasarkan aspek penyusunnya, tingkat pengetahuan masyarakat mengenai penggunaan bibit dalam pengembangbiakan tanaman obat berada dalam kategori sedang atau kurang tahu dengan persentase sebesar $63.5 \%$.

Pengetahuan masyarakat mengenai bibit yang digunakan untuk membudidayakan tanaman obat lebih banyak menggunakan bibit yang diperoleh dari tetangga yang berada di lingkungan sekitar. Selain itu, masyarakat juga kurang mengetahui secara pasti teknik pengembangbiakan yang tepat untuk tanaman obat yang dibudidayakan. Hal ini dapat dilihat dari adanya cara pengembangbiakan tanaman obat yang berbeda pada masing-masing tanaman, ada tanaman yang dikembangbiakkan dengan menggunakan biji, cangkokan, anakan, hingga stek batang. Tanaman obat yang dibudidayakan dengan cara stek batang beberapa diantaranya adalah sirih dan brotowali. Pengembangbiakan tanaman dengan cara stek rimpang dapat dilihat pada tanaman kunyit, rame, temulawak, dan kencur. Tanaman yang dibudidayakan dengan cara dicangkok diantaranya adalah mahkota dewa, sirsak, hingga jambu biji, sedangkan tanaman yang dapat dikembangbiakkan dengan tunas diantaranya adalah kapulaga.

Aspek berikutnya adalah penggunan pupuk. Pengetahuan masyarakat mengenai penggunaan pupuk tergolong pada kategori sedang yaitu sebesar $63.5 \%$. Masyarakat lebih familiar dengan pupuk kandang yang dapat diperoleh dengan mudah. Selain itu, masyarakat juga memiliki pertimbangan lain dalam memilih pupuk terutama dari segi ekonomi. Hasil 
observasi lapang menunjukkan bahwa masyarakat memiliki pengetahuan tersendiri dalam penggunaan pupuk. Ada sebagian masyarakat yang menggunakan penyedap rasa kemasan yang dicampur air. Masyarakat percaya bahwa air campuran penyedap rasa ini dapat memperbanyak buah dan menyuburkan tanaman. Namun, bagi masyarakat pupuk bukan merupakan aspek yang begitu penting dalam membudidayakan tanaman obat. Bila masyarakat tidak dapat menemukan atau memperoleh pupuk kandang maka masyarakat tidak memupuk tanamannya.

Pengetahuan masyarakat mengenai pemeliharaan tanaman obat tergolong sedang atau dengan persentase sebesar $64.7 \%$. Hal ini menunjukkan bahwa pemeliharaan yang dilakukan oleh masyarakat merupakan pemeliharaan yang bersifat tradisional dan didasarkan pada tradisi dan kebiasaan masyarakat. Bentuk pemeliharaan yang umum dilakukan adalah menyiangi gulma yang ada di sekitar tanaman. Bentuk pemeliharaan lain yang dilakukan adalah dengan menata posisi tanaman dan bahkan ada pula yang memagari tanaman untuk melindungi tanaman dari serangan hewan pengganggu lainnya. Aspek berikutnya yang digunakan untuk mengukur panca usahatani masyarakat yaitu pengolahan lahan. Persentase pengetahuan masyarakat mengenai pengolahan lahan yaitu sebesar $65.9 \%$. Masyarakat tidak terlalu fokus dalam pengolahan lahan. Pengolahan lahan yang sering dilakukan oleh masyarakat yaitu dengan cara menggemburkan tanah dengan cangkul atau peralatan seadanya ketika hendak menanam tanaman. Masyarakat belum mengenal tata cara pengolahan lahan yang tepat. Selain itu masyarakat juga lebih memilih cara yang praktis dalam pengolahan lahan sehingga pengolahan lahan biasanya hanya dilakukan sesaat sebelum kegiatan penanaman dilakukan.

Aspek terakhir yang dianalisis yaitu pengetahuan masyarakat mengenai pengairan pada tanaman obat yang ada di lahan pekarangan. Pengetahuan masyarakat mengenai pengairan tanaman obat tergolong sedang dengan persentase sebesar $70.6 \%$. Kondisi ini dapat disebabkan karena masyarakat lebih banyak mengetahui tentang cara pengairan secara manual dengan intensitas penyiraman rata-rata dua kali sehari. Masyarakat kurang mengetahui teknik-teknik pengairan yang dapat dilakukan untuk mengairi tanaman obat yang ada di pekarangan. Bahkan tidak sedikit masyarakat yang hanya memanfaatkan air hujan sebagai sarana atau bahan pengairan bagi tanaman yang ada di pekarangan.

\section{Pengetahuan Tentang Manfaat Tanaman Obat untuk Konsumsi}

Tanaman obat selain bermanfaat bagi kesehatan, juga dapat dimanfaatkan untuk memenuhi berbagai keperluan termasuk untuk memenuhi kebutuhan konsumsi sehari-hari rumah tangga. Tanaman obat yang ada di pekarangan dapat dijadikan sebagai alternatif pemenuhan kebutuhan rumah tangga seperti keperluan bumbu dapur, sebagai lalapan, hingga sebagai sayur makan. Pengetahuan lokal masyarakat mengenai tanaman obat untuk konsumsi rumah tangga diukur menggunakan tiga indikator yaitu pengetahuan, sikap, dan tindakan. Berdasarkan hasil observasi yang telah dilakukan, pengetahuan masyarakat mengenai tanaman obat untuk konsumsi rumah tangga relatif sedang atau kurang tahu dengan persentase sebesar $77.6 \%$. Masyarakat umumnya hanya mengkonsumsi tanaman obat yang sudah lazim digunakan untuk keperluan sehari-hari. seperti cabe, salam dan bumbu dapur lainnya. Selain itu, faktor kebiasaan yang ada di keluarga dalam mengkonsumsi tanaman juga menjadi salah satu penyebab tingkat pengetahuan berada dalam kategori sedang.

Indikator selanjutnya yaitu sikap masyarakat dalam mengkonsumsi tanaman obat dan ketersediaan melakukan penyebaran informasi. Sikap masyarakat terhadap konsumsi tanaman obat secara umum tergolong cukup setuju dikonsumsi dengan persentase sebesar $42.3 \%$. Hal ini dapat disebabkan karena ada beberapa jenis tanaman obat yang lazim dimanfaatkan sebagai alternatif dalam pemenuhan kebutuhan konsumsi rumah tangga, seperti tanaman salam, rempah-rempah, hingga tanaman yang dapat dijadikan sebagai sayur. Seperti halnya aspek pengetahuan, sikap masyarakat terhadap konsumsi tanaman obat juga didasarkan pada kebiasaan dan gaya hidup yang diterapkan oleh masyarakat. Kebiasaan rumah tangga yang jarang mengkonsumsi tanaman obat untuk memenuhi kebutuhan sehari-hari menyebabkan sikap masyarakat untuk mengkonsumsi tanaman obat cenderung negatif atau tidak bersedia dikonsumsi untuk memenuhi kebutuhan sehari- 
hari, dan begitu pula sebaliknya. Hal ini dapat dilihat dari hasil observasi lapang yang menunjukkan bahwa ada masyarakat yang tidak setuju mengkonsumsi tanaman obat dengan alasan aroma tanaman obat yang tidak sedap dan rasa pahit dari tanaman.

Indikator terakhir dalam aspek pengetahuan lokal mengenai konsumsi bagi rumah tangga yaitu tindakan. Tindakan konsumsi tanaman obat masyarakat Desa Ciherang tergolong kadangkadang dengan persentase sebesar $65.9 \%$. Hal ini dapat disebabkan karena sebagian besar masyarakat banyak yang tidak menanam beragam jenis tanaman obat di lahan pekarangan yang mereka miliki. Selain itu, ketersediaan tanaman tersebut juga terbatas sehingga konsumsi akan tanaman tersebut tidak intens dilakukan. Tanaman yang paling sering dijumpai dan dikomsumsi oleh rumah tangga yaitu tanaman cabe atau dengan persentase sebesar $83.5 \%$, jahe dengan persentase sebesar 70.59, kunyit sebesar 68.24 , sereh sebesar $55.29 \%$ dan kencur dengan persentase sebesar $54.12 \%$. Tanaman ini umum dikonsumsi masyarakat sehari-hari karena tanaman tersebut merupakan tanaman rempah-rempah yang mayoritas dibutuhkan oleh rumah tangga dalam pemenuhan kebutuhan dapur masyarakat.

Berdasarkan ketiga indikator yang telah dipaparkan sebelumnya, dirumuskan tingkat pengetahuan lokal mengenai konsumsi tanaman obat. Tingkat pengetahuan lokal masyarakat Desa Ciherang mengenai konsumsi tanaman obat tergolong sedang dengan persentase masyarakat sebesar $62.4 \%$. Tanaman obat biasanya hanya dikenal sebagai tanaman yang khusus untuk menyembuhkan sakit. Tanaman obat juga umumnya dipakai ketika sedang dibutuhkan atau sewaktu-waktu sedang sakit. Pengetahuan masyarakat yang tergolong sedang mengenai jenis-jenis tanaman obat yang dapat dijadikan sebagai alternatif bagi pemenuhan konsumsi rumah tangga inilah yang kemudian menyebabkan tindakan dari masyarakat tergolong rendah dalam aspek pemanfaatan tanaman obat untuk pemenuhan konsumsi. Berdasarkan hasil tersebut maka diperoleh data keseluruhan mengenai pengetahuan masyarakat terhadap konsumsi tanaman obat yang tergolong sedang, sedangkan pengetahuan masyarakat yang tergolong rendah sebesar $23.5 \%$ dan yang tergolong tinggi sebesar $14.1 \%$.

\section{Pengetahuan Mengenai Manfaat Tanaman Obat untuk Kesehatan}

Berdasarkan hasil observasi lapang yang telah dilakukan, diperoleh hasil pengetahuan lokal mengenai tanaman obat untuk kesehatan. Pengukuran pengetahuan lokal menggunakan tiga indikator yaitu pengetahuan, sikap dan tindakan. Data yang diperoleh menunjukkan bahwa $71.8 \%$ masyarakat Desa Ciherang merasa kurang tahu mengenai manfaat tanaman obat bagi kesehatan. Hal ini dikarenakan pengetahuan masyarakat akan tanaman obat bagi kesehatan relatif seragam, atau beberapa jenis tanaman saja yang sering dimanfaatkan atau sering digunakan ketika masyarakat sakit. Persentase masyarakat yang tahu takaran dosis tanaman obat yaitu sebanyak 18 orang atau sebesar $21.1 \%$. Hal ini dikarenakan masing-masing individu memiliki takaran atau dosis yang berbeda satu sama lainnya sehingga tidak ada takaran yang pasti mengenai dosis dari tanaman obat itu sendiri.

Indikator selanjutnya yang digunakan untuk melihat pengetahuan lokal masyarakat mengenai tanaman obat bagi kesehatan yaitu sikap. Masyarakat setuju tanaman obat berguna bagi kesehatan yaitu dengan persentase sebesar $51.8 \%$. Masyarakat cenderung memilih obatobatan tradisional dibandingkan dengan obatobatan modern karena masyarakat percaya obatobatan tradisional tidak memiliki efek samping, lebih murah, mudah didapat hingga tersedia kapanpun dibutuhkan.

Indikator terakhir dapat dilihat berdasarkan tindakan dari masyarakat mengenai manfaat tanaman obat bagi kesehatan. Tindakan masyarakat mengenai tanaman obat yang dimanfaatkan untuk kesehatan tergolong kedalam menyebarluaskan informasi ke keluarga dengan persentase sebesar $43.6 \%$. Hal ini karenakan masyarakat Desa Ciherarng tinggal berdasarkan ikatan kekeluargaan, dimana antar tetangga masih memiliki hubungan darah atau keluarga. Oleh karena itu, ketika ada anggota keluarga yang sakit atau kerabat yang sakit maka penyebaran informasi mengenai manfaat tanaman obat akan dilakukan. Penyebarluasan ini dilakukan sebagai wujud dari kepedulian antar sesama masyarakat satu sama lainnya.

Ketiga indikator yang telah dipaparkan sebelumnya digunakan untuk melihat tingkat 
pengetahuan masyarakat Desa Ciherang mengenai manfaat tanaman obat bagi kesehatan. Tingkat pengetahuan masyarakat mengenai manfaat tanaman obat bagi kesehatan tergolong tinggi dengan persentase sebesar $49.4 \%$. Hal ini dikarenakan masyarakat masih sering menggunakan atau memanfaatkan tanamantanaman obat yang ada di pekarangan jika diperlukan atau ketika sedang sakit. Selain itu, pengetahuan masyarakat akan tanaman-tanaman obat yang ada di pekarangan juga relatif sedang. Pengetahuan yang dimiliki oleh masyarakat sejalan juga dengan sikap serta tindakan dari masyarakat dalam pemanfaatan dan penyebarluasan tanaman obat yang memiliki manfaat bagi kesehatan. Masyarakat juga sering menggunakan dan memakai obat-obatan tradisional karena berbagai pertimbangan yang lebih banyak menguntungkan dibandingkan dengan obat-obatan modern. Selain itu, masyarakat yang hidup dengan ikatan kekeluargaan memiliki banyak pengaruh dalam penyebaran kegunaan tanaman obat.

\section{Tingkat Pengetahuan Masyarakat Desa Ciherang mengenai Tanaman Obat}

Hasil temuan di lapang menunjukkan bahwa terjadi perbedaan tingkat pengetahuan lokal yang dimiliki oleh masyarakat berdasarkan kelompok usia masyarakat. Masyarakat yang memiliki usia dengan kategori dewasa awal memiliki tingkat pengetahuan lokal yang lebih rendah bila dibandingkan dengan masyarakat yang tergolong ke dalam usia dewasa dan tua. Perbedaan tingkat pengetahuan ini dapat disebabkan karena masyarakat yang tergolong dalam kategori dewasa awal relatif jarang memanfaatkan tanaman obat. Selain itu, penyebaran informasi mengenai pengetahuan lokal yang dimiliki oleh masyarakat sudah mulai jarang dilakukan oleh generasi sebelumnya. Hal inilah yang menyebabkan tingkat pengetahuan lokal masyarakat yang tergolong dalam kategori dewasa awal lebih rendah bila dibandingkan dengan kelompok usia lainnya.

Berdasarkan hasil pengumpulan data yang telah dilakukan diperoleh data bahwa tingkat pengetahuan lokal masyarakat Desa Ciherang tergolong sedang dengan persentase sebagai $68.2 \%$. Gambaran singkat mengenai tingkat pengetahuan lokal masyarakat Desa Ciherang dapat dilihat pada Gambar 2.

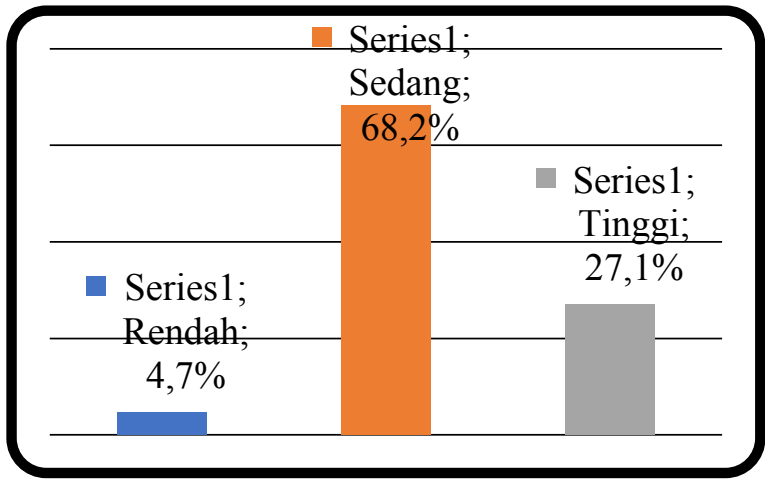

Gambar 2 Persentase tingkat pengetahuan lokal masyarakat Desa Ciherang Tahun 2015

Pengetahuan lokal masyarakat Desa Ciherang yang tergolong sedang ini disebabkan karena adanya perbedaan tingkat pengetahuan lokal antara masyarakat yang tergolong dalam kategori dewasa awal, dewasa, hingga tua. Selain itu, pengetahuan masyarakat mengenai tanaman untuk konsumsi rumah tangga pun juga relatif sedang. Hal ini dikarenakan pengetahuan masyarakat mengenai tanaman obat relatif sedang jika dimanfaatkan untuk kebutuhan konsumsi rumah tangga, karena masyarakat beranggapan bahwa tanaman obat digunakan untuk kesehatan masyarakat. Persepsi serta anggapan dari masyarakat inilah yang kemudian menyebabkan pengetahuan masyarakat mengenai tanaman obat memiliki manfaat bagi kesehatan tergolong tinggi, dimana masayarakat masih sering menggunakan tanaman-tanaman obat sebagai alternatif penyembuhan jika sedang sakit disamping menggunakan obat-obat medis.

Kesediaan masyarakat mengkonsumsi tanaman obat dikarenakan berbagai alasan dimana tanaman obat herbal memiliki berbagai keuntungan bagi masyarakat. Keuntungan yang dirasakan oleh masyarakat Desa Ciherang diantaranya memiliki khasiat tinggi, pertimbangan ekonomis, tidak memiliki efek samping, praktis karena langsung diambil di pekarangan. Pengaruh budaya, pandangan hidup serta keyakinan pada khasiat obat tradisional itu sendiri yang menyebabkan masyarakat tetap menggunakan ramuan atau obat-obat tradisional. Keyakinan ini muncul karena obat-obatan tersebut sudah dipakai secara turun temurun, dari generasi ke generasi. Selain itu, peran tokoh masyarakat juga memiliki pengaruh yang besar dalam penyebaran informasi kepada masyarakat sekitar. Tokoh atau personal yang dimaksud 
adalah pengguna yang sudah berpengalaman, peramu obat-obatan (tukang jamu) dan dukun beranak (mak paraji). Tokoh tersebut melakukan penyebaran informasi dengan memberitahu masyarakat mengenai khasiat obat-obatan tradisonal dan dibuktikan dengan kesembuhan yang telah diperoleh. Berdasarkan hasil observasi yang telah dilakukan, masyarakat Desa Ciherang masih tetap mempercayai dan memiliki keyakinan mengenai khasiat tanaman obat yang dapat menyembuhkan sakit, pemulihan habis melahirkan, dikonsumsi rumah tangga sebagai alternatif pemenuhan kebutuhan hidup hingga digunakan sebagai bahan untuk hal ghaib. Masyarakat Desa Ciherang memanfaatkan berbagai jenis tanaman obat bagi kesehatan dan penyembuhan sakit.

Berdasarkan pengumpuln data yang dilakukan diketahui bahwa tanaman yang paling familiar digunakan oleh masyarakat untuk kesehatan yaitu tanaman sirih dengan persentase sebesar $91.7 \%$. Tanaman ini sering digunakan karena memiliki khasiat yang banyak, selain digunakan oleh golongan tua untuk nyirih tanaman ini juga sering dipakai untuk kesehatan kaum wanita. Tanaman yang merambat ini juga tidak banyak membutuhkan lahan pekarangan dalam hal budidaya. Tanaman lainnya yang juga memiliki manfaat bagi kesehatan, seperti tanaman kumis kucing yang dipercaya dapat menyembuhkan sakit kencing manis, kunyit untuk menyembuhkan sakit maag, membersihkan bagian dalam perut pasca melahirkan, dan patah tulang. Tanaman mengkudu atau lebih sering disebut dengan nama cangkudu oleh masyarakat sering digunakan untuk menyembuhkan sakit darah tinggi, dan asam urat. Selain digunakan untuk menyembuhkan sakit, buah cangkudu ini juga sering dimakan atau dijadikan rujak oleh masyarakat. Bagian lain yang bisa dimanfaatkan dari tanaman cangkudu ini yaitu pucuk daun atau daun muda cangkudu. Daun muda ini biasa diolah oleh masyarakat sebagai sayur atau urap dan bahan tambahan untuk nasi goreng.

Tanaman selanjutnya yang dipercaya oleh masyarakat memberikan manfaat bagi kesehatan dan juga sebagai alternatif penopang dapur yaitu tanaman yang tergolong rempah-rempah atau bumbu masak seperti jahe, kencur dan salam. Selain digunakan untuk keperluan dapur, tanaman jahe juga dapat menyembuhkan batuk dan demam, kencur untuk batuk dan menambah nafsu makan, sedangkan salam untuk mengobati sakit darah tinggi. Tanaman saga dipercaya oleh masyarakat dapat menyembuhkan sariawan sehingga tanaman ini banyak dibudidayakan oleh masyarakat. Jambu batu dan sirsak yang tergolong tanaman berkayu juga ditemui di lahan pekarangan masyarakat. Seiring dengan perkembangan pengetahuan dan pengalaman empiris serta pewarisan pengetahuan secara turun temurun dalam mengenal manfaat dari tanaman-tanaman untuk kesehatan, tanaman jambu batu dan sirsak digunakan untuk menyembuhkan berbagai penyakit. Selain dipercaya untuk aspek kesehatan, ada juga tanaman yang dipercaya dapat memberikan manfaat secara spiritual. Hal ini dapat dilihat dari tanaman kelor, tanaman ini sering digunakan oleh masyarakat untuk menghilangkan "ilmu" seseorang, sehingga individu yang bersangkutan dapat meninggal dengan tenang. Hal ini menunjukkan bahwa tanaman obat tersebut juga memiliki nilai mistis dimata masyarakat.

Namun generasi muda saat ini mulai meninggalkan praktek pengetahuan lokal mengenai tanaman obat. Bahkan tidak sedikit generasi muda yang tidak mengenal berbagai jenis tanaman obat yang ada di lahan pekarangan. Generasi muda mulai cenderung bersikap apatis atau tidak peduli dengan khasiat dan kegunaan tanaman obat. Salah satu indikator yang menyebabkan melunturnya pengetahuan mengenai tanaman obat disebabkan karena kurangnya proses warisan informasi secara turun temurun dari satu generasi kegenerasi berikutnya atau dari orang tua kepada anaknya. Selain itu, adanya mindset atau persepsi dari generasi muda bahwa tanaman obat memiliki rasa yang tidak enak ketika dikonsumsi.

Meskipun demikian, pengetahuan lokal masyarakat masih tetap dipraktekkan. Situmorang dan Harianja (2014) mengemukakan bahwa eksistensi pengetahuan lokal dalam pemanfaatan tanaman obat oleh masyarakat Etnik Karo dapat disebabkan karena adanya adat istiadat, kepercayaan, pandangan hidup, pertimbangan ekonomis, kemudahan akses, media massa dan penyuluhan, tokoh atau orang lain hingga tingkat keseriusan penyakit. Berdasarkan faktor yang dikemukakan oleh Situmorang dan Harianja (2014) tersebut terdapat beberapa faktor yang juga ditemukan di 
Desa Ciherang. Faktor-faktor ini ikut menentukan eksistensi pengetahuan lokal yang masih dijaga oleh masyarakat Desa Ciherang. Berikut akan dipaparkan lebih lanjut mengenai faktor-faktor yang juga ditemukan di Desa Ciherang.

\section{Pandangan hidup atau kepercayaan}

Tradisi dan kebudayaan yang dimiliki oleh masyarakat Desa Ciherang turut menjadi salah satu indikator yang menentukan eksistensi pengetahuan lokal megenai tanaman obat yang ada di pekarangan. Pengetahuan ini diwariskan secara turun temurun sehingga masyarakat menjadi percaya dan terbiasa untuk memanfaatkan tanaman obat. Kepercayaan masyarakat dalam memanfaatkan tanaman obat juga didasarkan pada pengalaman yang dimiliki oleh anggota keluarga maupun tetangga sekitar. Selain itu, masyarakat juga beranggapan bahwa tanaman obat sebagai bahan dasar obat tradisional cenderung aman bagi kesehatan dan tidak memberikan efek samping.

\section{Pertimbangan ekonomis}

Masyarakat Desa Ciherang masih tetap memanfaatkan tanaman obat yang ada di lahan pekarangan karena lebih menguntungkan secara ekonomis. Tanaman obat dapat digunakan tanpa harus mengeluarkan biaya yang relatif besar. Selain itu, tanaman obat yang ada di pekarangan juga dapat dimanfaatkan untuk memenuhi kebutuhan sehari-hari rumah tangga tanpa harus mengeluarkan biaya tambahan untuk membeli kebutuhan. Tanaman obat yang ada di pekarangan dapat dijadikan sebagai rempahrempah, lalapan, hingga beberapa jenis tanaman yang dapat dijadikan sebagai bahan untuk memasak.

\section{Kemudahan akses dalam memperoleh dan memanfaatkan tanaman obat}

Tanaman obat yang ada di lahan pekarangan baik yang sengaja dibudidayakan maupun tidak memiliki arti penting bagi masyarakat Desa Ciherang. Tanaman ini dimanfaatkan untuk kesehatan hingga memenuhi kebutuhan seharihari. Bahkan tanaman liar yang dianggap sebagai rumput atau gulma oleh sebagian besar masyarakat justru dapat dimanfaatkan sebagai tanaman obat. Hal ini didasarkan pada pengetahuan yang dimiliki oleh masyarakat Desa Ciherang. Adanya tanaman obat yang tumbuh secara liar menunjukkan bahwa umumnya tanaman obat tidak membutuhkan teknik budidaya dan perawatan khusus. Lokasi tanaman obat yang dapat dijumpai di sekitar tempat tinggal masyarakat khususnya di wilayah pekarangan memberikan kemudahan kepada masyarakat untuk mengakses dan memanfaatkan tanaman obat ketika dibutuhkan.

\section{Tingkat Pengelolaan Tanaman Obat Di Desa Ciherang}

Tanaman obat dapat dimanfaatkan sebagai salah satu alternatif strategi nafkah bagi masyarakat. Tingkat pengelolaan tanaman obat dapat dilihat dari dua aspek utama yaitu tanaman obat yang dijadikan sebagai sumber nafkah dan usaha pemanfaatan tanaman obat untuk memperoleh nafkah. Tanaman obat yang dimanfaatkan sebagai sumber nafkah digolongkan menjadi tiga kategori yaitu rendah (kurang dari 8 tanaman), sedang (8 hingga 17 tanaman), dan tinggi (lebih dari 17 tanaman). Hasil di lapang menunjukkan bahwa $49.4 \%$ masyarakat memanfaatkan 8 hingga 17 tanaman obat di lahan pekarangan sebagai sumber nafkah bagi keluarga. Hal ini dikarenakan tidak semua masyarakat Desa Ciherang menjadikan tanaman obat yang ada di lahan pekarangan sebagai sumber nafkah bagi keluarga. Beberapa keluarga menanam tanaman hanya untuk penghijauan, menanam tanaman obat dalam skala kecil sehingga tidak begitu terasa manfaat yang diperoleh bagi rumah tangga.

Meskipun demikian, ada pula masyarakat yang tergolong tinggi dalam memanfaatkan tanaman obat sebagai sumber nafkah. Masyarakat yang tergolong tinggi dalam pemanfaatan tanaman obat ini berprofesi sebagai dukun beranak atau sering disebut sebagai mak paraji, tukang pijat, tukang jamu, dan masyarakat yang terbiasa memanfaatkan tanaman obat tersebut di dalam keluarga. Profesi masyarakat tersebut membuat masyarakat menggunakan tanaman obat dan menjadikannya sebagai sumber nafkah bagi keluarga. Tanaman obat yang ada di lahan pekarangan dapat dijadikan sebagai sumber nafkah bagi masyarakat, dimana masyarakat memperoleh penghasilan dari pemanfaatan tanaman obat yang ada. Selain dimanfaatkan untuk memperoleh penghasilan, tanaman obat juga dapat dijadikan sebagai alternatif dalam memenuhi kebutuhan dapur seperti tanaman 
rempah-rempah, lalapan hingga tanaman yang dapat dijadikan sebagai sayur. Adanya pemanfaatan tanaman yang ada di lahan pekarangan mampu menekan pengeluaran bagi rumah tangga jika dimanfaatkan secara optimal. Hal ini dapat dilihat dari pemanfaatan tanaman oleh warga Desa Ciherang. Masyarakat yang memiliki tanaman obat di lahan pekarangan dengan mudah memanfaatkan tanaman tersebut untuk memenuhi kebutuhan sehari-hari seperti tanaman rempah-rempah dan lalapan. Selain itu, masyarakat Desa Ciherang juga mengemukakan bahwa tanaman obat yang ada di pekarangan lebih memudahkan masyarakat dalam mengakses dan memperoleh obat ketika dibutuhkan.

Tanaman obat yang dijadikan sebagai sumber nafkah ini kemudian dimanfaatkan untuk memenuhi kebutuhan dengan cara yang berbedabeda. Hal ini kemudian disebut dengan usaha untuk mendapatkan nafkah. Usaha untuk memanfaatkan tanaman obat memperoleh nafkah yang dilakukan oleh masyarakat Desa Ciherang tergolong dalam kategori cukup beragam dengan persentase sebesar $37.7 \%$. Hasil ini tidak berbeda jauh dengan usaha masyarakat untuk memperoleh nafkah yang tidak beragam yaitu sebanyak 29 orang atau sebesar $34.1 \%$. Kondisi ini disebabkan karena sebagian besar masyarakat memanfaatkan tanaman obat untuk dikonsumsi sendiri guna memenuhi kebutuhan rumah tangga dan pemanfaatan bagi kesehatan. Selain itu, masyarakat Desa Ciherang juga belum terlalu mengenal istilah komersil terhadap pengolahan dan pemanfaatan tanaman obat, sehingga proses pendistribusian dan pemanfaatan tanaman obat lebih didasarkan pada ikatan kekeluargaan dan ikatan ketetanggaan.

Masyarakat yang memperoleh penghasilan dengan memanfaatkan tanaman obat cenderung beragam atau memiliki variasi dalam mengola tanaman obat. Berdasarkan informasi yang diperoleh di lapang, tampak bahwa secara umum masyarakat lebih banyak memanfaatkan tanaman obat dengan cara dikonsumsi dengan persentase sebesar $84.12 \%$. Hal ini dikarenakan tanaman obat yang ada di pekarangan dijadikan sebagai alternatif untuk memenuhi kebutuhan sehari-hari atau sebagai penopang dapur rumah tangga dan dapat juga dimanfaatkan bagi kesehatan masyarakat. Meskipun usaha masyarakat untuk memanfaatkan tanaman obat didominasi dengan cara mengkonsumsi langsung, ada pula masyarakat yang melakukan usaha lainnya seperti dibuat bibit kembali dengan persentase sebesar $10.13 \%$. Hal ini dilakukan oleh masyarakat guna menjaga keberlanjutan dan stabilitas produksi tanaman yang ada di lahan pekarangan. Usaha-usaha lain yang juga dilakukan oleh masyarakat yaitu dengan cara dijual sebesar $3.65 \%$, diolah sebesar $1.82 \%$ dan ditanam di lokasi lain sebesar $0.27 \%$. Umumnya masyarakat tidak menjual hasil produksi tanaman yang mereka miliki, beberapa jenis dan sebagian masyarakat saja yang menjual hasil produksi tanaman obat yang mereka miliki. Hal ini dikarenakan hubungan yang terjalin antar sesama masyarakat didasarkan pada ikatan kekeluargaan dan ikatan ketetanggaan. Meskipun demikian, ada juga masyarakat yang mengola tanaman obat menjadi ramuan dan memiliki khasiat tinggi serta dapat dimanfaatkan untuk kesembuhan pasca melahirkan. Namun, hanya beberapa warga saja yang menanam tanaman obat di lokasi lain.

Tingkat pengelolaan tanaman obat masyarakat Desa Ciherang dapat dilihat berdasarkan dua indikator yang telah dipaparkan sebelumnya. Tingkat pengelolaan tanaman obat masyarakat Desa Ciherang digolongkan menjadi tiga kategori yaitu rendah, sedang, dan tinggi. Gambaran singkat mengenai tingkat strategi nafkah masyarakat Desa Ciherang dapat dilihat pada Gambar 2.

Tingkat pengelolaan tanaman obat di Desa Ciherang tergolong tinggi yaitu sebesar $40.00 \%$. Hal ini dikarenakan banyak masyarakat yang menjadikan tanaman obat sebagai sumber nafkah bagi rumah tangga. Selain itu, usaha untuk memanfaatkan tanaman obat tergolong cukup beragam sehingga mampu memenuhi kebutuhan nafkah rumah tangga. Mayoritas masyarakat memanfaatkan tanaman obat dengan cara dikonsumsi langsung dalam hal pemenuhan nafkah, seperti tanaman obat-obatan yang dapat pula dijadikan sebagai alternatif pemenuhan kebutuhan sehari-hari seperti rempah-rempah, lalapan hingga sayur. Pemanfaatan tanaman obat yang dilakukan oleh masyarakat didasari karena pengetahuan yang diwariskan secara turun temurun dari generasi sebelumnya. 


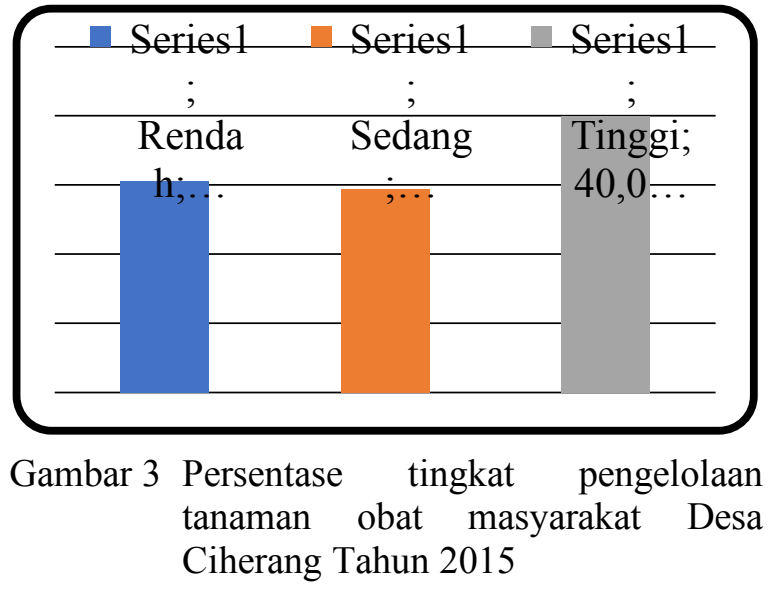

Adanya kesadaran dalam diri masyarakat untuk mengkonsumsi dan memanfaatkan tanaman obat yang ada di lahan pekarangan tidak terlepas dari keyakinan mereka terhadap khasiat tanaman tersebut. Sebagian dari masyarakat juga memanfaatkan tanaman yang ada dengan cara menjual hasil produksi tanaman yang diperoleh, memanfaatkan tanaman obat yang ada untuk menyembuhkan sakit tertentu, mengolah tanaman menjadi ramuan dan jamu serta memanfaatkan tanaman untuk keperluan dapur seperti rempah-rempah.

Cara pengelolaan tanaman atau usaha yang dilakukan dalam hal memperoleh nafkah ini membuat masyarakat dapat menekan pengeluaran rumah tangga. Berdasarkan hasil temuan di lapang, banyak manfaat yang diperoleh oleh masyarakat karena memanfaatkan tanaman obat yang ada di lahan pekarangan. Selain menghemat biaya, tanaman obat ini juga dapat digunakan sewaktu-waktu diperlukan dalam keadaan mendesak sekalipun, tidak memberikan efek samping, hingga dapat memperoleh uang hasil menjual tanaman yang ada atau hasil menjual olahan dari tanaman tersebut. Pemanfaatan tanaman obat yang dijadikan sebagai pemenuhan konsumsi secara langsung merupakan salah satu usaha masyarakat dalam memenuhi kebutuhan nafkah.

Hasil pengumpulan data yang telah dilakukan menunjukkan bahwa pendapatan masyarakat Desa Ciherang didominasi oleh masyarakat dengan pendapatan rendah atau kurang dari satu juta rupiah dengan persentase sebesar 38.8\%. Namun hal ini tidak jauh berbeda dengan masyarakat yang memiliki pendapatan kategori sedang dengan persentase sebesar $35.3 \%$, dan masyarakat yang memiliki pendapatan dengan kategori tinggi sebesar 25.9\%. Berdasarkan data yang diperoleh tampak bahwa kelompok masyarakat yang paling banyak melakukan pengelolaan tanaman obat adalah kelompok masyarakat dengan kategori pendapatan yang tergolong sedang.

Tanaman obat yang ada di lahan pekarangan sering dimanfaatkan oleh masyarakat sebagai alternatif pengobatan ketika dibutuhkan atau sedang sakit. Pemanfaatan atau pengelolaan tanaman obat secara tidak langsung juga berdampak pada kondisi kesehatan masyarakat. Kondisi kesehatan masyarakat secara umum berada dalam kategori sedang dengan persentase sebesar $66.7 \%$. Kondisi kesehatan masyarakat yang berada pada kategori tinggi sebesar 33.3\% dan tidak ada masyarakat yang berada pada kategori rendah. Kondisi kesehatan masyarakat yang tergolong sedang ini dapat disebabkan karena adanya pengelolaan dan pemanfaatan tanaman obat oleh masyarakat. Masyarakat memanfaatkan tanaman obat untuk mengobati flu, batuk, pilek, pegal-pegal, dan meriang. Tanaman obat juga dimanfaatkan untuk mengobati sakit yang tergolong sedang hingga berat seperti maag kronis dan ambeien. Meskipun demikian tidak sedikit masyarakat yang mengkonsumsi obat warung atau obat medis untuk mengobati sakit yang tergolong dalam penyakit ringan seperti batuk dan pilek. Masyarakat lebih memilih untuk mengkonsumsi obat warung karena dinilai lebih praktis dan ekonomis dimana biaya untuk membeli obat relatif murah. Ada pula masyarakat yang mengkombinasikan tanaman obat dan obat medis baik yang diperoleh dari warung maupun dari rumah sakit.

\section{Hubungan Pengetahuan Lokal Dengan Tingkat Pengelolaan Tanaman Obat}

Hasil pengumpulan data yang dikemukakan sebelumnya menunjukkan bahwa pengetahuan lokal masyarakat mengenai tanaman obat berada dalam kategori sedang. Hal ini dapat dilihat pada Tabel 1.

Tabel 1 Jumlah dan persentase masyarakat Desa Ciherang menurut tingkat pengetahuan lokal mengeni tanaman obat Tahun 2015

\begin{tabular}{cccc}
\hline No & $\begin{array}{c}\text { Tingkat pengetahuan } \\
\text { lokal masyarakat } \\
\text { mengenai tanaman obat }\end{array}$ & $\begin{array}{c}\text { Jumlah } \\
\text { (orang) }\end{array}$ & $\begin{array}{c}\text { Persentase } \\
(\%)\end{array}$ \\
\hline 1 & Rendah & 4 & 4.7 \\
\hline
\end{tabular}




\begin{tabular}{rlrr}
\hline 2 & Sedang & 58 & 68.2 \\
3 & Tinggi & 23 & 27.1 \\
\hline & Total & 85 & 100.0 \\
\hline
\end{tabular}

Tabel 1 menunjukkan bahwa tingkat pengetahuan lokal masyarakat berada pada kategori sedang dengan persentase sebesar $68.2 \%$. Selain itu, tingkat pengelolaan tanaman obat masyarakat tergolong tinggi. Hal ini dapat dilihat pada Tabel 2.

Tabel 2 Jumlah dan persentase masyarakat Desa Ciherang menurut tingkat pengelolaan tanaman obat Tahun 2015

\begin{tabular}{llcc}
\hline No & $\begin{array}{c}\text { Tingkat pengelolaan } \\
\text { tanaman obat }\end{array}$ & $\begin{array}{c}\text { Jumlah } \\
\text { (orang) }\end{array}$ & $\begin{array}{c}\text { Persentase } \\
(\%)\end{array}$ \\
\hline 1 & Rendah & 26 & 30.6 \\
2 & Sedang & 25 & 29.4 \\
3 & Tinggi & 34 & 40.0 \\
\hline & Total & 85 & 100.0 \\
\hline
\end{tabular}

Tabel 2 menunjukkan bahwa tingkat pengelolaan tanaman obat yang dilakukan oleh masyarakat Desa Ciherang tergolong tinggi dengn persentase sebesar $40.0 \%$. Berdasarkan data yang diperoleh ini kemudian dilakukan pengolahan data berupa tabulasi silang untuk melihat gambaran umum kedua variabel yang diukur. Gambaran singkat kedua variabel dapat dilihat pada Tabel 3.

Berdasarkan Tabel 3 dapat dikaji lebih lanjut mengenai variabel tingkat pengetahuan lokal dengan tingkat strategi nafkah masyarakat. Data yang diperoleh menunjukkan bahwa tidak terdapat hubungan antara tingkat pengetahuan lokal dengan strategi nafkah masyarakat. Hal ini dapat diketahui dengan melihat kategori masingmasing variabel. Masyarakat yang memiliki tingkat pengetahuan lokal dengan kategori

Tabel 3 Jumlah dan persentase masyarakat Desa Ciherang menuruttingkat pengetahuan lokal dan tingkat pengelolaan tanaman obat Tahun 2015

\begin{tabular}{|c|c|c|c|c|c|c|c|c|c|}
\hline \multirow{3}{*}{ No } & \multirow{3}{*}{$\begin{array}{c}\text { Tingkat } \\
\text { pengetahuan lokal }\end{array}$} & \multicolumn{6}{|c|}{ Tingkat pengelolaan tanaman obat masyarakat } & \multirow{2}{*}{\multicolumn{2}{|c|}{ Total }} \\
\hline & & \multicolumn{2}{|c|}{ Rendah } & \multicolumn{2}{|c|}{ Sedang } & \multicolumn{2}{|c|}{ Tinggi } & & \\
\hline & & $\mathrm{n}$ & $\%$ & $\mathrm{n}$ & $\%$ & $\mathrm{n}$ & $\%$ & $\mathrm{n}$ & $\%$ \\
\hline 1 & Rendah & 1 & 25.0 & 2 & 50.0 & 1 & 25.0 & 4 & 100.0 \\
\hline 2 & Sedang & 19 & 32.8 & 16 & 27.6 & 23 & 39.7 & 58 & 100.0 \\
\hline 3 & Tinggi & 6 & 26.1 & 7 & 30.4 & 10 & 43.5 & 23 & 100.0 \\
\hline & Total & 26 & 30.6 & 25 & 29.4 & 34 & 40.0 & 85 & 1000 \\
\hline
\end{tabular}

\section{Hubungan \\ Kondisi Agroekosistem Pekarangan dengan Pengetahuan Lokal Masyarakat Mengenai Tanaman Obat}

Berdasarkan pemaparan sebelumnya, kondisi agroekosistem pekarangan masyarakat Desa Ciherang sudah diolah dan dimanfaatkan secara optimal. Hal ini dapat dilihat dari tidak adanya rendah secara umum memiliki tingkat pengelolaan tanaman obat dengan kategori sedang. Tingkat pengetahuan lokal masyarakat yang tergolong sedang memiliki persebaran data dengan kategori tinggi pada tingkat pengelolaan tanaman obat masyarakat. Kondisi yang berbeda ditemukan pada masyarakat yang memiliki tingkat pengetahuan dengan kategori tinggi, dimana tingkat pengelolaan tanaman obat masyarakat juga tergolong tinggi. Ketidaksesuaian antar masing-masing kategori variabel merupakan salah satu penyebab tidak terdapatnya hubungan antara variabel yang diuji.

Hasil ini didukung oleh hasil uji Rank Spearman untuk melihat hubungan kedua variabel. Data yang diperoleh menunjukkkan bahwa tidak terdapat hubungan yang signifikan diantara kedua variabel yang diuji. Hal ini dapat dilihat dari nilai signifikansi uji statistik kedua variabel sebesar 0.577 dimana nilai signifikansi yang ada lebih besar dari alfa yang telah ditetapkan ( $p>$ $0.05)$. Hal ini dikarenakan kurang beragamnya usaha yang dilakukan oleh masyarakat dalam memanfaatkan tanaman obat. Mayoritas masyarakat memanfaatkan tanaman obat dengan cara mengkonsumsi langsung tanpa didasarkan pada pengetahuan lokal yang dimiliki. Namun bila dilihat berdasarkan variabel penyusun pengetahuan lokal, tingkat pengetahuan budidaya tanaman obat dengan tingkat pengelolaan tanaman obat memiliki hubungan yang paling signifikan diantara variabel-variabel lainnya. Hal ini dapat dilihat dari nilai signifikansi uji statistik dimana uji statistik kedua variabel tersebut sebesar $0.027(\mathrm{p}<0.05)$. 
menggunakan pot dan disusun dengan rapi di tempat yang tersedia. Selain itu, masyarakat umumnya hanya menanam beberapa jenis tanaman saja di pinggir-pinggir atau sudut rumah, sedangkan masyarakat yang memiliki lahan pekarangan luas biasanya menanam tanaman lebih banyak dan lebih variatif. Kegiatan budidaya tanaman yang dilakukan oleh masyarakat tidak terlepas dari pengetahuan yang mereka miliki. Pengetahuan ini dapat bersumber dari pengetahuan sebelumnya yang diperoleh dari keluarga, tetangga, dan lingkungan sekitar. Meskipun demikian, ada juga beberapa masyarakat yang memanfaatkan lahan pekarangan dengan menanam berbagai jenis tanaman karena tuntutan profesi.

Profesi sebagai mak paraji atau lebih sering dikenal dengan sebutan mak berang banyak memerlukan tanaman-tanaman obat untuk membantu kesembuhan pasca melahirkan. Pemanfaatan lahan pekarangan yang dilakukan semata-mata hanyalah untuk lebih mempermudah akses dalam memperoleh tanaman obat. Selain profesi sebagai mak berang, profesi lain yang memanfaatkan lahan pekarangan karena tuntutan pekerjaan yaitu tukang urut dan tukang jamu. Pengetahuan yang dimiliki oleh masyarakat ini kemudian membuat masyarakat untuk membudidayakan tanaman obat di lahan pekarangan. Berbagai manfaat yang dapat dirasakan oleh masyarakat seperti tanaman obat yang memiliki khasiat tinggi dan tanpa efek samping, kemudahan dalam memperoleh dan pertimbangan ekonomis juga menjadi pertimbangan masyarakat untuk menanam tanaman obat di lahan pekarangan mereka.

\section{SIMPULAN DAN SARAN}

\section{Simpulan}

Masyarakat Desa Ciherang telah mengelola dan memanfaatkan agroekosistem pekarangan yang ada di sekitar tempat tinggal masyarakat. Data dan observasi di lapang menunjukkan bahwa kondisi agroekosistem pekarangan masyarakat sudah dimanfaatkan dengan optimal. Hal ini dapat dilihat dari tidak adanya pekarangan yang ditelantarkan dan tidak dimanfaatkan oleh masyarakat. Masyarakat menanam berbagai jenis tanaman obat yang dapat dijadikan sebagai rempah-rempah hingga lalapan. Kondisi agroekosistem juga dapat dilihat dari tiga indikator yang terdiri dari kebijakan, pemerataan, dan keberlanjutan. Masyarakat Desa Ciherang memiliki kebijakan penuh untuk menentukan tanaman apa saja yang ditanam di lahan pekarangan. Umumnya hasil produksi ini dimanfaatkan pula kepada tetangga atau kerabat yang membutuhkan, sedangkan aspek keberlanjutan dapat dilihat dari cara masyarakat dalam membudidayakan tanaman obat tersebut.

Pengelolaan dan pemanfaatan tanaman obat di lahan pekarangan tidak lepas dari pengetahuan lokal yang dimiliki oleh masyarakat. Hasil penelitian di lapang menunjukkan bahwa pengetahuan lokal masyarakat Desa Ciherang tergolong dalam kategori sedang dengan persentase sebesar $68.2 \%$. Pengetahuan ini diperoleh berdasarkan warisan turun temurun dari generasi sebelumnya. Bila dilihat berdasarkan komponen penyusun pengetahuan lokal yang terdiri dari pengetahuan mengenai budidaya tanaman, pengetahuan mengenai manfaat untuk konsumsi tanaman, pengetahuan mengenai panca usahatani secara umum berada dalam kategori sedang. Hanya pengetahuan mengenai manfaat bagi kesehatan yang tergolong tinggi.

Tanaman obat yang ada di lahan pekarangan dapat dikelola dan dimanfaatkan sebagai sumber nafkah masyarakat. Hasil pengolahan data yang dilakukan menunjukkan bahwa tingkat pengelolaan tanaman obat di Desa Ciherang tergolong tinggi dengan persentase sebesar $40.0 \%$. Tingkat pengelolaan tanamn obat dapat dilihat dari jumlah tanaman yang dimanfaatkan sebagai sumber nafkah dan usaha dalam memanfatkan tanaman obat untuk mendapatkan nafkah. Tanaman obat dapat dimanfaatkan dengan beberapa cara seperti dikonsumsi langsung, dijual, diolah, dijadikan bibit, hingga ditanam di lokasi lain. Secara umum masyarakat memanfaatkan tanaman obat dengan cara dikonsumsi langsung baik untuk sebagai alternatif pangan maupun pemanfaatan bagi kesehatan. Kelompok yang paling banyak memanfaatkan tanaman obat adalah masyarakat dengan pendapatan sedang. Pengelolaan tanaman obat juga berdampak terhadap kondisi kesehatan masyarakat. Data di lapang menunjukkan bahwa kondisi kesehatan masyarakat berada dalam kategori sedang dengan persentase sebesar $66.7 \%$. 
Berdasarkan data yang diperoleh mengenai tingkat pengetahuan lokal dan tingkat pengelolaan tanaman obat dilakukan uji statistik untuk melihat hubungan kedua variabel. Pengolahan data yang dilakukan menunjukkan bahwa tidak terdapat hubungan nyata antara kedua variabel yang diuji. Apabila dilakukan uji statistik berdasarkan variabel penyusunnya maka tingkat pengetahuan mengenai budidaya tanaman obat memiliki nilai signifikansi terhadap strategi nafkah masyarakat. Selain itu, berdasarkan observasi lapang yang telah dilakukan tampak bahwa pengetahuan lokal yang dimiliki oleh masyarakat ikut menentukan kondisi agroekosistem pekarangan masyarakat.

\section{Saran}

Pengetahuan lokal masyarakat yang berada dalam kategori sedang perlu ditingkatkan kembali untuk menjamin keberlanjutan dan eksistensi pengetahuan lokal yang ada di masyarakat. Selain itu, hal ini juga diharapkan dapat memanfaatkan lingkungan secara optimal khususnya di lahan pekarangan. Langkah yang dapat dilakukan untuk meningkatkan pengetahuan lokal yang ada di masyarakat khususnya mengenai tanaman obat dapat dilakukan dengan cara membentuk paguyuban sebagai wadah untuk mentransfer ilmu pengetahuan serta pengalaman yang berkaitan dengan pengolaan tanaman obat yang ada di pekarangan. Pembentukan paguyuban ini harus melibatkan generasi-generasi muda agar pengetahuan yang ada tetap lestari. Langkah berikutnya yang dapat dilakukan yaitu mengikutsertakan masyarakat yang dituakan dan yang dianggap memiliki pengetahuan lebih tentang tanaman obat. Akademisi juga dapat ikut berperan dalam meningkatkan pengetahuan lokal masyarakat. Akademisi dapat ikut mengkoordinir atau sebagai fasilitator dalam kegiatan yang dilakukan masyarakat terutama mengenai pengelolaan dan pemanfaatan tanaman obat. Bagi aparat pemerintahan khususnya aparat Desa Ciherang diharapkan dapat mendukung program-program yang berhubungan dengan pengembangan pengetahuan lokal masyarakat dan berpartisipasi aktif.

\section{DAFTAR PUSTAKA}

Djauhariya E, Hernani. 2004. Tanaman Berkhasiat Obat. Jakarta (ID): Penebar Swadaya.
Ellis F. 2000. Rural Livelihoods and Diversity in Developing Countries. New York (US): Oxford University.

Haryadi S. 2013. Manfaatkan pekarangan sebagai penyuplai gizi keluarga untuk mendukung ketahanan pangan rumah tangga menuju keluarga yang sehat, produktif dan berkualitas. [internet] [diunduh 2015 Jan 19]. Tersedia pada: http://bkp.ntbprov.go.id/berita-165pekarangan-sumber-gizi-keluarga.html

Hartati S. 2011. Tanaman hias berkhasiat obat. Bogor (ID): IPB Press.

Hudin F. 2010. Pengetahuan Lokal pada Pengelolaan Jati dalam Pengembangan Hutan Rakyat (Studi Kasus Masyarakat Desa Loji, Kecamatan Simpenan, Kabupaten Sukabumi, Provinsi Jawa Barat ). [skripsi]. [internet]. [diunduh 2015 Jan 17]. Tersedia pada: http://repository.ipb.ac.id/handle/1234567 89/63506

Ivancevich JM, Konopaske R, Matteson MT. 2005. Perilaku dan Manajemen Organisasi. Judul asli: Organizational Behavior and Management Seventh Edition. Alih bahasa: Gina Gania. Editor: Wibi Hardani dan Bimo Adi Yoso. Jakarta [ID]: Erlangga. [Diunduh 2015 Jan 12]. Tersedia pada: http://books.google.co.id/books?id=uunaj num4cgC\&pg $=$ PA301\&hl=id\&source $=\mathrm{gb}$ $\underline{\text { s selected pages } \& \mathrm{cad}=2 \# \mathrm{v}=\text { onepage } \& \mathrm{q} \&}$ $\mathrm{f}=$ false

[Litbang] Badan Penelitian dan Pengembangan Pertanian. 2012. Ayo Mengenal Tanaman Obat. Jakarta (ID).

Marten GG. 1988. Productivity, Stability, Sustainability, Equitability and Autonomy as Properties for Agroecosystem Assessment. Agricultural Systems [internet]. [Diunduh 2015 Jan 12]. Tersedia pada: http://gerrymarten.com/publicatons/pdfs/G M_AgroecosystemAssessment.pdf

Munawwarah SM. 2012. Kajian Pemanfaatan Tumbuhan Obat Pada Masyarakat Etnis Simalungun di Kecamatan Sipispis Kabupaten Serdang Bedagai. [internet]. 
[Diunduh 2015 Jan 17]. Tersedia pada: http://repository.usu.ac.id/handle/1234567 89/34722

Rahayu dan Prawiroatmodjo. 2005. Keanekaragaman tanaman pekarangan dan pemanfaatannya di Desa Lampeapi, Pulau Wawoni-Sulawesi Tenggara. Jurnal Tek.Ling [Internet]. Diunduh 2015 Mei 7]; 06(02): 160-364. Tersedia pada: ejurnal.bppt.go.id/index.php/JTL/article/vi ew/425/489

Rahmawati R, Subair, Idris, Gentini, Ekowati D, Setiawan U. 2008. Pengetahuan Lokal Masyarakat Adat Kasepuhan: Adaptasi, Konflik, dan Dinamika Sosio-Ekologis [internet]. Sodality. [Diunduh 2015 Jan 17] 02(02): 151-190. Tersedia pada: download.portalgaruda.org/article.php? a rticle $=83580$ \& val $=223$

Reijntjes C, Haverkort B, Bayer AW. 1999. Pertanian Masa Depan: Pengantar untuk Pertanian Berkelanjutan dengan Input Luar Rendah. Yogyakarta [ID]: Kanisius. [internet]. [Diunduh 2015 Jan 12]. Tersedia pada: https://books.google.co.id/books?id=5jPE 8wAZbuIC\&pg=PA19\&lpg=PA19\&dq $=\mathrm{a}$ groekosistem + merupakan + ........\&source $=$ b1\&ots=VV22QsRM0T\&sig $=$ UKyNkz360 oG4RSKLY50ynnrRAf8\&hl=id\&sa $=$ X\&e $\mathrm{i}=\mathrm{K} 12 \mathrm{zVKS} 3 \mathrm{HcaNuASev} 4 \mathrm{HoBw} \&$ redir_e $\mathrm{sc}=\mathrm{y} \# \mathrm{v}=$ onepage $\& \mathrm{q}=$ agroekosistem $\% 20 \mathrm{~m}$ erupakan $\% 20 \ldots \ldots . . . \& \mathrm{f}=$ false

Saragih E. 2010. Perilaku ibu primipara dalam merawat bayi baru lahir di Kelurahan Sukaraja Kecamatan Medan Maimun.[skripsi].[internet]. [Diunduh 2015 Jan 13]. Tersedia pada: http://repository.usu.ac.id/handle/1234567 $\underline{89 / 17142}$

Sari NI.2011. Studi Etnobotani Tumbuhan Herba Pada Masyarakat Karo di Kawasan Taman Nasional Gunung Leuser (Studi Kasus di Desa Telagah Kecamatan Sei Bingai Kabupaten Langkat)"dalam waktu yang telah ditetapkan. [internet]. [Diunduh 2015 Jan 17]. Tersedia pada: http://repository.usu.ac.id/bitstream/12345 6789/23394/4/Chapter\%20II.pdf
Scoones I. 1998. Sustainable Rural Livelihoods A Framework for Analysis. Working Paper 72. Brighton [Uk]. Institute for Development Studies. [Diunduh 24 November 2014]; Tersedia pada: http://mobile.opendocs.ids.ac.uk/opendocs /handle/123456789/3390

Singarimbun M, Effendi S. 2006. Metode Penelitian Survey. Jakarta (ID): LP3ES.

Situmorang dan Harianja. 2014.Pengetahuan dan pemanfaatan tumbuhan obat tradisional masyarakat Suku Moronene di Desa RauRau Sulawesi Tenggara. [internet]. [diunduh 2015 April 26]. Tersedia pada ojs.uho.ac.id/index.php/wallacea/article/d ownload/43/36

Soetomo S. 2002. Strategi desain ruang suburban dalam menopang pembangunan yang berkelanjutan: merajut ruang yang beragam dari pedesaan ke perkotaan. [internet] [diunduh 2015 Jan 18]. Tersedia pada:

http://eprints.undip.ac.id/290/1/Sugiono_S oetomo.pdf

Suharti S. 2014. Pemanfaatan pekarangan [internet]. [Diunduh 2015 Mei 18]. Tersedia pada: http://cybex.pertanian.go.id/files/.../PEMA NFAATAN\% 20PEKARANGAN.pdf

Suharyat P. 2009. Hubungan Antara Sikap, Minat dan Perilaku Manusia. [internet]. [Diunduh 2015 Jan 12].Region: 1 (3). Tersedia pada http://download.portalgaruda.org/article.p hp? article $=19324 \&$ val $=1225$

Sunaryo, Joshi L. 2003. Peranan Pengetahun Ekologi Lokal dalam Sistem Agroforesti. Bogor (ID): World Agroforestry Centre (ICRAF). [internet]. [diunduh 2015 Jan 17]. Tersedia pada: http://www.worldagroforestry.org/downlo ads/publications/PDFs/rp03101.PDF

Suryana Y, Iskandar J. Supratman U. 2014. Studi pengetahuan lokal tanaman obat pada agroekosistem pekarangan dan dinamika perubahannya di Desa Cibunar Kecamatan Rancakalong Kabupaten Sumedang-Jawa Barat [internet]. Bionatura. [diunduh 2015 Jan 18] 16(01): 
19-25. Tersedia pada: http://www.google.co.id/url?sa=t\&rct=j\& $\mathrm{q}=\&$ esrc $=\mathrm{s} \&$ source $=$ web $\& \mathrm{~cd}=1 \& \mathrm{cad}=\mathrm{rja}$ \&uact $=8 \& v e d=0$ CB4QFjAA\&url $=\mathrm{http} \% 3$ A $\% 2 \mathrm{~F} \% 2 \mathrm{Fbionatura}$.unpad.ac.id\%2Fwpcontent $\% 2$ Fuploads $\% 2 F 2014 \% 2 F 08 \% 2 F 4$ -SURYANA.pdf\&ei $=$ zS7VLvVFNCJuATqo4CIAQ\&usg=AFQjC NGlE4u1NIxeorWhYVaa5cXTqlPwHw\& sig2=XuSgHLKI9w5fD6UWjsWStA

Syamsir E. 2013. Budidaya tanaman obat untuk murid sekolah dasar. Bogor [ID]: Seafast center IPB. [internet].[diunduh 2015 Mei 7]. Tersedia pada: https://seafast.ipb.ac.id/tpcproject/wp.../tanaman-obat-sd-seri-3.pdf

Wardana HD, Barwa NS, Kongsjahju A, Iqbal MA, Khalid M, Taryadi RR. 2002. Budidaya secara organik: Tanaman obat rimpang. Depok (ID): Penebar Swadaya.

Yulianto E.H. 2013. Konservasi tradisional berbasis kearifan lokal masyarakat tani Kabupaten Paser (Studi kasus Desa Semuntai Kecamatan Long Ikis Kabupaten Paser). Agrifor [internet].[Diunduh 2014 Okt 08]; 07 (02) : 140-147. Tersedia pada http://ejurnal.untagsmd.ac.id/index.php/A G/article/view/345 
Rosmanita \& Saharuddin / JSKPM 1(3): 359-378 